\title{
Performance of Moment Resisting RC Frames under Repeated Earthquakes Containing Fling-Step Effect
}

\author{
Ade Faisal, Afiful Anshari, Bambang Hadibroto
}

\begin{abstract}
The ground motion record from near-field earthquake may have forward and backward directivity effects. The first has pulse and fling-step signatures in its velocity and displacement motions, respectively. It is well recognized that the ground motion with pulse and fling-step effects amplified the building drift larger than the ground motion with no pulse and fling-step effects. The building damage also occurs due to earthquakes that are not singly exhibited. This includes the ground motion with fling-step, which is not many studied so far, especially in comparison with ground motion with pulse effect. Therefore, the goals of this study are to find out the effect of repeated earthquakes containing fling-step on the reinforced concrete (RC) moment resisting frames (MRF) in form of interstory drift ratio (IDR) and collapse probability. The 5-, 10-, and 15-story $R C$ frames are taking into account as special, moderate and ordinary MRF, which is based on the $R$-factor of $R$ $=8, R=5$, and $R=3$. Based on the result of incremental dynamic analysis, the cumulative distribution function is statistically developed to define the fragility function. This function is treated as the probability of collapse of $R C$ frames. The result shows that the performance of $R C$ frames induced by single ground motion containing fling-step is at least 2 times larger than the single ground motion with pulse effect. The repeated earthquakes containing fling-step effect propagate the drift of 1.32 and 1.50 times larger than single earthquake with fling-effect. These motions cause the 10- and 15-story $R C$ frames with $R=8$ to have $100 \%$ of probability of collapse.
\end{abstract}

Keywords: Interstory drift; Nonlinear response history analysis; Probability of collapse.

\section{INTRODUCTION}

Indonesia and Philippines are South East Asia countries that mainly situated in highly seismic prone region. The seismic event causes all affected infrastructures in earth surface move to all direction. The movement could cause damage to structures which in turn it could endanger the occupant. The empirical research of reinforced concrete (RC) frames affected by strong vibration indicates the clear relation between interstory drift and failure of structure. Kappos and Manafpour [1] shows that critical interstory drift of $2 \%$ occurs at the level 7 of 10 story RC building due to strong earthquake. Negro et al. [2] conducts pseudo-dynamic test to the 4 story RC building that resulted $7,18 \%$ of critical

Revised Manuscript Received on October 22, 2019

* Correspondence Author

Ade Faisal, Fakultas Teknik, Universitas Muhammadiyah Sumatera Utara, Medan, Indonesia. Email: adef@umsu.ac.id

Afiful Anshari, Earthquake Engineering Research Group, Universitas Muhammadiyah Sumatera Utara, Medan, Indonesia. Email: afifulanshari@gmail.com

Bambang Hadibroto*, Fakultas Teknik, Universitas Negeri Medan, Medan, Indonesia. Email: hadibroto@unimed.ac.id interstory drift for damage state. The 10 story RC building experiences initial damage at the column when interstory drift reaches $3 \%$ [3]. These studies are conducted to the certain level of damage state based on single quake, which might be extended to the near collapse when the building experiencing another earthquake vibration.

The recent studies show that the sequence of earthquake causes more extensive damage to the structures [4]. These are also found in Hatzigeorgiou and Liolios [5] and Faisal et al. [6] which explain that multi-story moment resisting frames experience extensively damage due to multiple earthquake in comparison with the single earthquake effect. Recent studies regarding repeated earthquake are conducted using single degree of freedom system by Zhai et al. [7,8] in order to investigates the damage and the reduction factor. Hatzivassiliou and Hatzigeorgiou [9] evaluates the extensive damage of $\mathrm{RC}$ frames due to repeated earthquakes in more detail using three dimensional model. Amiri and Rajabi [10] investigate 6 type of RC and steel structures under multiple earthquakes. Recent studies evaluate the probability of collapse for RC frames and its risk of damage under seismic sequences $[11,12,13]$. All of these find that the damage could extend sigficantly when the structures experience multiple earthquake in comparison with single earthquake effect.

Generally, the earthquake ground motion can be classified into far-field motion and near-field motion [14]. The near-field ground motion is defined as the earthquake ground motion that recorded in the seismic station with distance $\leq 15$ $\mathrm{km}$ from the fault rupture. It has a unique signature in their velocity and displacement forms which is not available in the far-field motion. The pulse effect could be found in the velocity ground motion of near-field earthquake whereas fling-step effect is in displacement ground motion. Kamai et al. [15] explains that the fling-step signature in the recorded motion appears as the effect of the permanent tectonic shifted of a rupturing fault. It is commonly depicted by a nonzero displacement at end of shaking in pair with a one-sided pulse in velocity record.

The significant effect of near-field ground motion with pulse (or fling-step) on the multi-story RC frames is explained in many references [16,17], either building with regular or with irregular plan $[18,19]$. An example of the response of 5-story RC frame under far- and -near-field ground motion is depicted in Figure 2. The figures clearly indicate that motion with pulse effect cause the drift larger 
than the drift due to regular motion. The effect is getting larger for this 5-story RC frame with high reduction factor (e.g. $\mathrm{R}=8$ ). The repeated near-field earthquake also propagates larger drift compared with the effect due to single earthquake. However, the effect of multiple earthquakes containing only near-field ground motion have not fully investigated yet, particularly the effect of multiple ground motion with fling-step on the moment resisting frame. Therefore, this study aims to investigate the performance of RC frames under repeated near-field ground motion containing fling-step effect.

\section{METHODS}

\section{A. RC Structures Model}

The evaluated moment resisting frames are consisted of 5-, 10-, and 15-story RC structures with regular shape of floor plan, masses and stiffness. The RC special moment resisting frame structures $(\mathrm{R}=8)$ are assumed to be built on the soft soil in Banda Aceh City, Indonesia, whereas the RC frame structures with $\mathrm{R}=5$ and $\mathrm{R}=3$ are assumed to be built on the medium and hard soil type, respectively, in the Palembang City, Indonesia. The plan view and the frame section of the structural model are depicted in Fig. 2. The length of all beam are identical of $6.0 \mathrm{~m}$ and the height of all columns is $3.5 \mathrm{~m}$, except at the ground floor is $4.5 \mathrm{~m}$ for the column height. All of the model have employed of $f_{c}$, $40 \mathrm{MPa}$ and $f_{y} 400 \mathrm{MPa}$ for the concrete and rebar yield strengths, respectively. Natural period of the structural model is of $0.41 \mathrm{~s}, 0.80 \mathrm{~s}$, and $1.16 \mathrm{~s}$, for 5-, 10-, and 15-story RC frames, respectively.

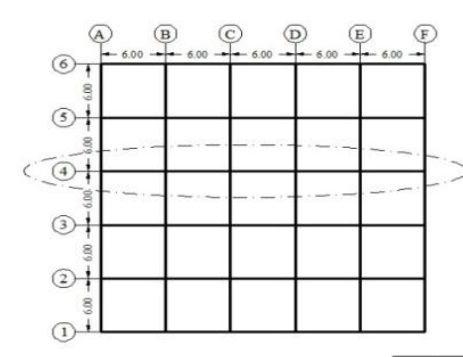

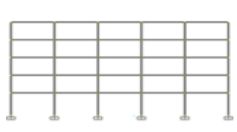

a)

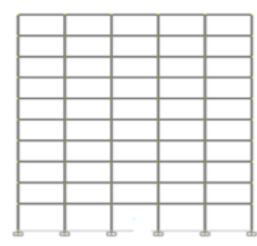

b)

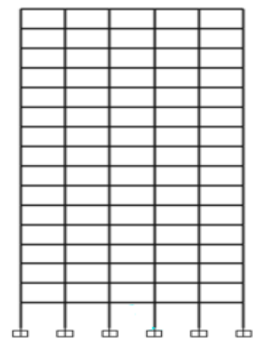

c)
Fig. 1. The plan view and frame section of 5-, 10-, and 15-story models used in this study.

The element strength in this study is defined based on FEMA method which is the yield force is taken from designed internal forces. The yield flexural strength (My) of element is taken from the elastic designed flexural force, whereas the maximum flexural force is based on empirical value of $1.13 \mathrm{My}$ [20]. The element's flexural forces are adjusted to fulfil the code requirement for strong column weak beam mechanism. The lumped plasticity model is employed for all elements using the rotation capacity proposed by Haselton et al. [20] and Takeda's model of hysteresis. The rotation capacity of $0.04 \mathrm{rad}$ is used for special MRF, whereas $0.02 \mathrm{rad}$ is used for medium and ordinary MRFs [20].

\section{B. Ground Motions and Intensity Measure}

The ground motion used in the study is selected from the available records in Pacific Earthquake Engineering Research (PEER) Next Generation Attenuation (NGA), COSMOS Strongmotion Data Center, and Kalkan and Kunnath [14]. The selection criteria are based on magnitude, near-field source-to-site distance $(\leq 15 \mathrm{~km})$, fault mechanism, and soil type. Table $1-2$ show the selected records containing near-field with pulse and fling-step effects, respectively. The intensity measure employed in this study is $\operatorname{RSA}\left(T_{1}\right)$. All the selected records are scaled up and down by referring the elastic designed spectral acceleration (Fig. 3a) at the natural period of the model considered, $R S A\left(T_{1}\right)$, as demonstrated in Fig. 3b. The design basis earthquake (DBE) (475-year earthquake) design spectra for Banda Aceh City is depicted in Fig. 3a.

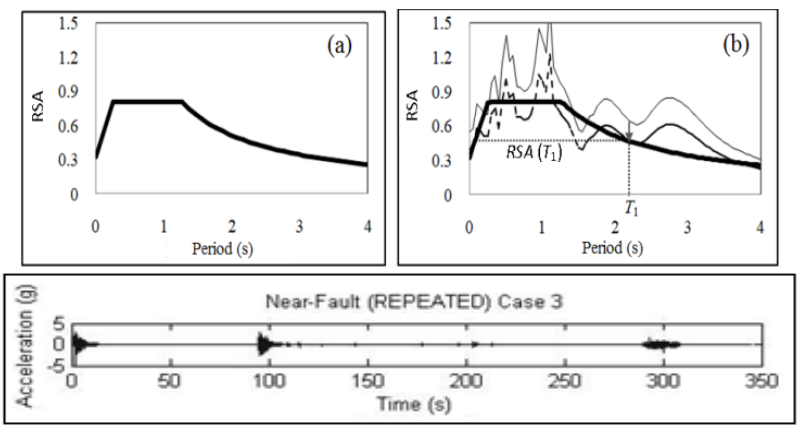

Fig. 2. Model of earthquake ground motion: a) Elastic design spectra for Banda Aceh City, b) Illustration of the ground motion scaling process, (c) example of 3 times repeated ground motions.

Table- I: Selected records of near-field ground motion containing pulse effect sourced from PEER NGA and COSMOS.

\begin{tabular}{|c|c|c|c|c|}
\hline No. & Earthquake name & Year & Station & Mw \\
\hline 1 & $\begin{array}{l}\text { Christchurch New } \\
\text { Zealand }\end{array}$ & 2011 & CBGS & 6.1 \\
\hline 2 & Chi-Chi Taiwan & 1999 & TCU129 & 6.2 \\
\hline 3 & Niigata japan & 2004 & NIG020 & 6.6 \\
\hline 4 & Chi-Chi Taiwan & 1999 & TCU129 & 7.6 \\
\hline 5 & Northwest China & 1997 & Jianshi & 5.8 \\
\hline 6 & Mendocino cape & 1992 & Petrolia CA & 6.6 \\
\hline 7 & Nocera Umbra & 1997 & NCR & 5.4 \\
\hline 8 & Nocera Umbra & 1997 & $\mathrm{NCR}$ & 5.7 \\
\hline 9 & Hokkaido japan & 2004 & HKD071 & 7.0 \\
\hline 10 & Tohoku japan & 2011 & MYG001 & 7.1 \\
\hline
\end{tabular}

Table- II: Selected records of near-field ground motion containing fling-step effect [14].

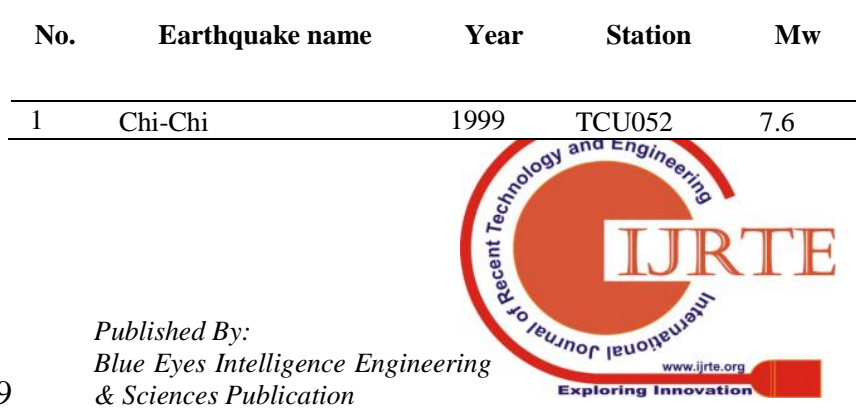




\begin{tabular}{lllll}
\hline 2 & Chi-Chi & 1999 & TCU068 & 7.6 \\
3 & Chi-Chi & 1999 & TCU074 & 7.6 \\
4 & Chi-Chi & 1999 & TCU084 & 7.6 \\
5 & Kocaeli & 1999 & Yarimca & 7.4 \\
6 & Kocaeli & 1999 & Izmit & 7.4 \\
7 & Kocaeli & 1999 & Sakarya & 7.4 \\
8 & Chi-Chi & 1999 & TCU072 & 7.6 \\
9 & Chi-Chi & 1999 & TCU065 & 7.6 \\
10 & Chi-Chi & 1999 & TCU071 & 7.6 \\
\hline
\end{tabular}

All the scaled ground motions are then paired randomly by adding the 50 second of zero motions in between two, and/or three scaled motions in order to model the repeated earthquakes (Fig. 3c). The addition of zero motion is to make the free vibration on the structure exhibit properly before the next earthquake motion started. The study used 2 times and 3 times repeated earthquakes to be induced on the $\mathrm{RC}$ frames model. The result is then compared with the effect due to single ground motion containing pulse and fling-step effect

\section{Structural Analysis and Collapse Limit State}

In design phase, the two dimensional of 3-, 10-, and 15 -story RC frames are analyzed with response spectrum method to get the design flexural force. The elastic design phase complies with the Indonesian Standard SNI 1726:2012 [21], which is identical with the ASCE 7-10 [22]. By employing the design force as the yield force of the elements as aforementioned, the static nonlinear analysis and nonlinear response history analysis are conducted to define the yield state and the collapse state of the system, respectively, using Ruaumoko 2D v.4.0 [23]. The collapse state is defined based on incremental dynamic analysis [24]. In incremental dynamic analysis (IDA), the intensity measure (IM) is repeatedly scaled in order to find the IM level at which each ground motion causes collapse. The state of collapse is based on interstory drift ratio of $10 \%$ that will cause global dynamic instability of structure [24]. The near collapse limit state of $2.5 \%$ is employed based on the requirement stipulated in Indonesian seismic code [21].

\section{Probability of Collapse}

The probability of building collapse (or any limit state of interest) is commonly expressed by fragility function, as a function of some ground motion IM such as response spectrum acceleration at period of considered building and damping. The parameters of fragility function are estimated based on statistical procedures using the data taken from either field observations of damage, expert opinion, static structural analyses, or nonlinear dynamic structural analysis. The mean annual rate of structural collapse can be predicted through combining this fragility function with a ground motion hazard function [25]. The fragility function is common developed through a log normal cumulative distribution function as follows [26]:

$$
P\left(C \mid R S A\left(T_{1}\right)=x\right)=\Phi\left(\frac{\operatorname{Ln}\left(R S A\left(T_{1}\right) / \theta_{R S A\left(T_{1}\right)}\right)}{\sigma_{\operatorname{Ln}\left(R S A\left(T_{1}\right)\right)}}\right)
$$

where $P\left(C \mid R S A\left(T_{1}\right)=x\right)$ is the probability of reaching or exceeding collapse state while the structure is induced by a ground motion with $R S A\left(T_{1}\right)=x ; \Phi($.$) is the standard normal$ cumulative distribution function; $\theta_{R S A(T l)}$ is the median of the ground motion that will cause collapse; and $\sigma_{\operatorname{Ln}(R S A(T 1))}$ is the standard deviation of the ground motion that will cause collapse. In developing the fragility function, the result from IDA is not all the time could achieve the targeted collapse limit state. A statistical tool proposed by Baker [26] is useful to repair the data in order to estimate the fragility function.

\section{RESULTS AND DISCUSSION}

The superior effect of ground motion earthquake containing fling-step on the 5-story RC frames can be seen in Fig. 4. It is evidently apparent that the drift caused by ground motion with the fling-step, as well as its repeated motion, is larger than the drift caused by the ground motion with pulse effect.

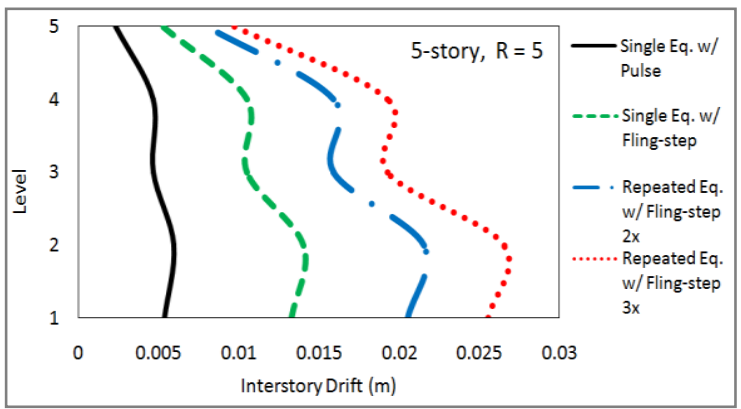

(a)

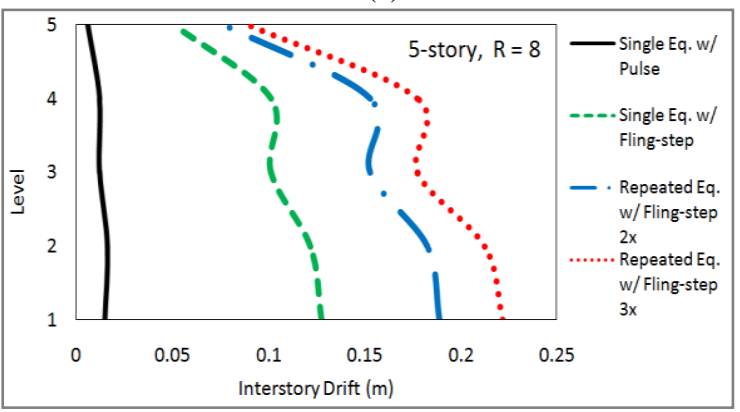

(b)

Fig. 4. Effect of single and repeated earthquakes containing fling-step effect on the interstory drift of 5-story frames: a) $R=5$, b) $R=8$.

The result of nonlinear response history analysis for 5-, 10-, and 15-story RC that designed accordingly with 475-year earthquake, which is so-called design basis earthquake (DBE), has clearly showed that single earthquake with fling-step propagated larger interstory drift ratio on the $\mathrm{RC}$ frames compared with the effect due to single earthquake with pulse. All frames affected by single earthquake with pulse effect perform in line with the near collapse limit state of $2.5 \%$ that required by the SNI 1726:2012 standard but 15 -story with $\mathrm{R}=8$. On the contrary, only 3 and 2 frames pass the standard's limit state when the single and repeated ground motion with fling-step, respectively, induced the frames. The increment of drift is evidently demonstrated after the repeated earthquakes induced the frames. 
These effects are getting larger as the story of frame, as well as the R-factor, increase. The trend of probability of collapse of the 5-, 10-, and 15-story RC frames can been seen in Fig. 5 - 7. The figure also depicts the comparison of collapse probability of all considered RC frames affected by single and repeated earthquakes containing pulse and fling-step effects. It shows the superior effect propagated by the earthquakes with fling-step on the RC frames in comparison with earthquake with pulse effect. For $\mathrm{R}=8$, the trend indicates the increment of probability of collapse as the story of RC frame increases when earthquakes with fling-step effect occurs, which is not the case for $R=5$ and $R=3$. It is explained that as $\mathrm{R}$-factor increased, the probability of collapse is increased as well.


Fig. 5. Probability of collapse of the $R C$ frames with $R=8$ affected by repeated earthquakes containing fling-step effect: a) 15-story, b) 10-story, c) 5-story.
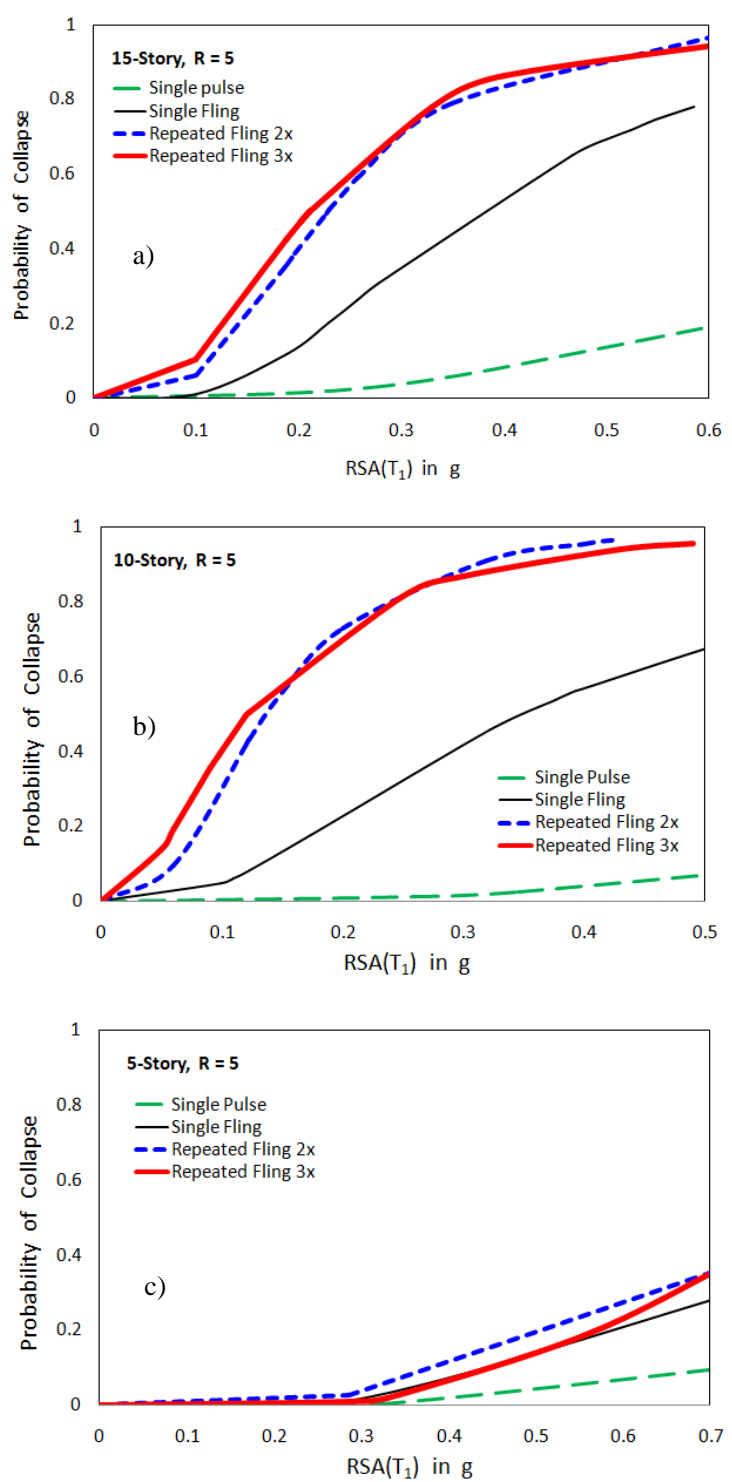

Fig. 6. Probability of collapse of the $R C$ frames with $R=5$ affected by repeated earthquakes containing fling-step effect: a) 15-story, b) 10-story, c) 5-story.

The 10-, and 15-story RC frames with $\mathrm{R}=8$ experience collapse when DBE earthquake, either single or repeated earthquakes with fling-step effect, induces the structures. Nevertheless, 5-story RC frame with $\mathrm{R}=8$ experiences probability of collapse exceeding $50 \%$ when those single and repeated earthquakes occur. The performance of all frames is contrary (<50\%) when the single earthquake with pulse-effect hits the frames. In general, only 5-story RC frames with $\mathrm{R}=5$ and $\mathrm{R}=3$ have probability of collapse < $5 \%$ if repeated earthquakes containing fling-step effect occurred. The result explains that the effect of single ground motion with fling-step on the interstory drift reaches at least 2 times larger than the effect due to ground motion with pulse. The result also indicates that the RC frames could collapse after experiencing the ground motion with fling-step, whereas it is not the case for the effect due to ground motion with pulse. The 2 times and 3 times repeated ground motions with fling-step clearly propagates the interstory drift of $\mathrm{RC}$

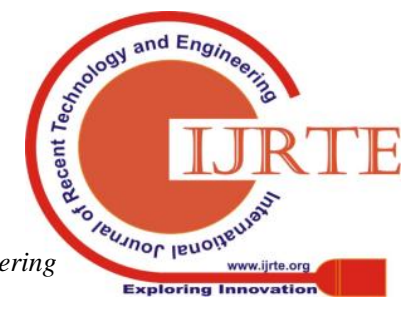


frames of 1.32 and 1.50 times larger than the single ground motion with fling step.
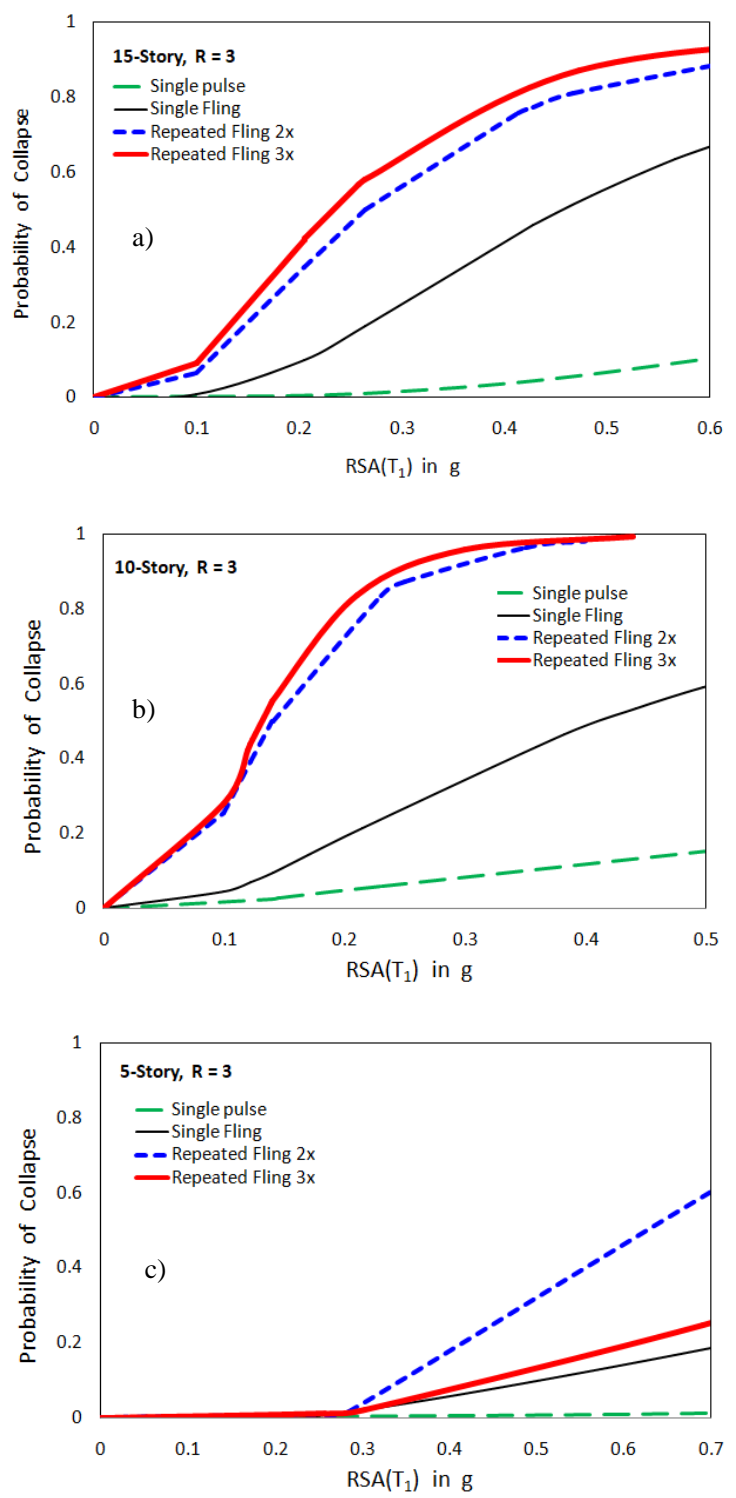

Fig. 7. Probability of collapse of $R C$ frames with $R=3$ affected by repeated earthquakes containing fling-step effect: a) 15-story, b) 10-story, c) 5-story.

\section{CONCLUSION}

This paper presents the performance of 5-, 10-, and 15-story RC frames under repeated earthquake ground motion containing fling-step effect. The result is compared with the performance of frames under single earthquakes containing pulse and fling-step effects. The performance is presented in interstory drift ratio and probability of collapse. The study concludes that the ground motion containing fling-step effect gives larger detrimental effect on the RC frames compared with the ground motion with pulse effect. The interstory drift of RC frames is clearly propagated by the 2 times and 3 times repeated ground motions with fling-step. In general, the collapse probability is increased as the story and R-factor increased for single and repeated earthquakes. Fully collapse is probably occurred on the 10- and 15-story $\mathrm{RC}$ frames having $\mathrm{R}=8$ when repeated earthquake containing fling-step (scaled to DBE) induced the frame. The rest of $\mathrm{RC}$ frames are secure from the collapse hazard, although it is still indicating significant probability of collapse.

\section{ACKNOWLEDGEMENT}

This study has been funded by internal grant of Universitas Muhammadiyah Sumatera Utara, Medan, Indonesia. The author wishes to thanks to my students who involved in this research as the computer numerator.

\section{REFERENCES}

1. A. Kappos, \& Manafpour, A., 2001. Seismic design of R/C buildings with the aid of advanced analytical techniques. Engineering Structures, 23, pp. 319-332.

2. P. Negro, Pinto, A.V., Verzeletti, G. and Magonette, G.E., 1996. PsD test on four-story R/C building designed according to Eurocodes. Journal of Structural Engineering, 122(12), pp.1409-1417.

3. C. Dymiotis, Kappos, A.J., Chryssanthopoulos, M.K., 1999. Seismic reliability of RC frames with uncertain drift and member capacity. Journal of Structural Engineering (ASCE) 125(9), pp.1038-1047.

4. C. Amadio, Fragiacomo, M., and Rajgelj, S., 2003. The effects of repeated earthquake ground motions on the non linear response of SDOF systems. Earthquake Engineering and Structural Dynamics, 32(2), pp.291-308.

5. G. D. Hatzigeorgiou, and Liolios, A. A., 2010. Nonlinear behaviour of RC frames under repeated strong ground motions. Soil dynamics and earthquake engineering, 30(10), pp.1010-1025.

6. A. Faisal, Majid, T. A., \& Hatzigeorgiou, G. D. 2013. Investigation of story ductility demands of inelastic concrete frames subjected to repeated earthquakes. Soil Dynamics and Earthquake Engineering, 44, pp.42-53.

7. C. H. Zhai, Wen, W. P., Li, S., \& Xie, L. L., 2015a. The ductility-based strength reduction factor for the mainshock-aftershock sequence-type ground motions. Bulletin of Earthquake Engineering, 13(10), pp.2893-2914.

8. C. H. Zhai, Zheng, Z., Li, S., \& Xie, L. L., 2015b. Seismic analyses of a RCC building under mainshock-aftershock seismic sequences. Soil Dynamics and Earthquake Engineering, 74, pp.46-55.

9. M. Hatzivassiliou \& Hatzigeorgiou, G. D., 2015. Seismic sequence effects on three-dimensional reinforced concrete buildings. Soil Dynamics and Earthquake Engineering, 72, pp.77-88.

10. G. G. Amiri, \& Rajabi, E., 2018. Effects of consecutive earthquakes on increased damage and response of reinforced concrete structures. Computers and Concrete, 21(1), pp.55-66

11. F. Jalayer \& Ebrahimian, H., 2017. Seismic risk assessment considering cumulative damage due to aftershocks. Earthquake Engineering \& Structural Dynamics, 46(3), pp.369-389.

12. F. Hosseinpour \& Abdelnaby, A. E., 2017. Fragility curves for RC frames under multiple earthquakes. Soil Dynamics and Earthquake Engineering, 98, pp.222-234.

13. F. Di Trapani \& Malavisi, M., 2019. Seismic fragility assessment of infilled frames subject to mainshock/aftershock sequences using a double incremental dynamic analysis approach. Bulletin of Earthquake Engineering, 17(1), pp.211-235.

14. E. Kalkan \& Kunnath, S. K., 2006. Effects of fling step and forward directivity on seismic response of buildings. Earthquake spectra, 22(2), pp.367-390.

15. R. Kamai, Abrahamson, N. and Graves, R., 2014. Adding fling effects to processed ground-motion time histories. Bulletin of the Seismological Society of America, 104(4), pp.1914-1929.

16. M. I. Adiyanto, Faisal, A., Majid, T.A., 2013. Nonlinear behaviour of reinforced concrete building under repeated earthquake excitation International Conference on Computer and Software Modeling, IPCSIT, Malaysia.

17. M. Z. A. Zahid, Majid, T. A., \& Faisal, A. (2012). Effect of repeated near field earthquake to the high-rise Rc building. Australian Journal of Basic and Applied Sciences, 6(10), 129-138.

18. T. A. Majid, Wan, H. W., Zaini, S. S., Faisal, A., \& Wong, Z. M. (2010) The effect of ground motion on non-linear performance of asymmetrical reinforced concrete frames. Disaster Advances, 3(4), 35-39. 
19. K. Rashidi, A., Majid, T.A., Fadzli, M.N., Faisal, A. and Noor, S.M., 2017, October. A comprehensive study on the influence of strength and stiffness eccentricities to the on-plan rotation of asymmetric structure. In AIP Conference Proceedings (Vol. 1892, No. 1, p. 120013). AIP Publishing.

20. C. B. Haselton, Liel, A. B., Deierlein, G. G., Dean, B. S., \& Chou, J. H., 2010. Seismic collapse safety of reinforced concrete buildings. I: Assessment of ductile moment frames. Journal of Structural Engineering, 137(4), pp.481-491.

21. Badan Standarisasi Nasional, 2012. Tata Cara Perencanaan Ketahanan Gempa Untuk Struktur Bangunan Gedung dan Non Gedung SNI 1726:2012. Jakarta: Departemen Pekerjaan Umum.

22. ASCE(2010) Minimum design loads for buildings and other structures, ASCE 7-10, Reston, VA.

23. A. J. Carr, 2010. Ruaumoko Manual Volume: 1, Theory and User Guide to Associated Program. University of Canterbury.

24. D. Vamvatsikos and Cornell, C.A., 2002. Incremental dynamic analysis. Earthquake Engineering \& Structural Dynamics, 31(3), pp.491-514.

25. L. F. Ibarra and Krawinkler, H., 2005. Global collapse of frame structures under seismic excitations (pp. 29-51). Berkeley, CA: Pacific Earthquake Engineering Research Center.

26. J. W. Baker 2015. Efficient analytical fragility function fitting using dynamic structural analysis. Earthquake Spectra, 31(1), pp.579-599.

\section{AUTHORS PROFILE}

Ade Faisal is senior lecturer at Civil Engineering Programme, Universitas Muhammadiyah Sumatera Utara, Medan, Indonesia. His research is focused on earthquake engineering and seismic hazard analysis.

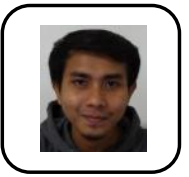

Afiful Anshari is Research Engineer at Earthquake Engineering Research Group, Universitas Muhammadiyah Sumatera Utara, Medan, Indonesia. His work deals with numerical modeling of structures.

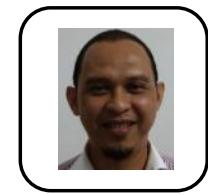

Bambang Hadibroto is senior lecturer at Faculty of Engineering and Construction, Universitas Negeri Medan, Medan, Indonesia. His research is focused on reinforced concrete structures. 